\title{
The Quality of Bali Beef from East Nusa Tenggara during Distribution Process from Slaughterhouse to Consumers
}

\author{
Kualitas Daging Sapi Bali asal Nusa Tenggara Timur selama Distribusi dari Rumah Potong Hewan sampai \\ ke Konsumen
}

\author{
A. Martiana ${ }^{1 *}$, I. I. Arief ${ }^{2}$, H. Nuraini ${ }^{2}$, \& E. Taufik ${ }^{2}$ \\ ${ }^{1}$ Graduate School of Animal Production Science and Technology, Faculty of Animal Science, IPB University \\ ${ }^{2}$ Department of Animal Production and Technology, Faculty of Animal Science, IPB University, \\ Agatis St, Campus IPB Darmaga, Bogor 16680, Indonesia \\ *Corresponding author: anggiamartiana@gmail.com \\ (Received 19-12-2019; Revised 23-12-2019; Accepted 14-01-2020)
}

\begin{abstract}
The aims of this study were to analyze the physicochemical quality and microbiological condition of Bali beef during distribution process from slaughterhouse to consumers. The study used six heads of Bali cattle from East Nusa Tenggara which were transported by Camara Nusantara cattle ship from East Nusa Tenggara (Kupang) to Tanjung Priok then they were slaughtered at Jatimulya slaughterhouse. Samples were taken from three points distribution: 1) at slaughterhouse, 2) at market, 3) at consumers' freezer (beef after 3 days at consumers' freezer). Observation on pH, water holding capacity, cooking loss and tenderness was done to measure the physicochemical quality of Bali beef. In terms of microbiology quantitative analysis of total plate count Escherichia coli, Staphylococcus aureus, and Salmonella sp were done on Bali beef. All data were analyzed statistically using two-way analysis of variance (ANOVA). The results showed that Bali beef during distribution had normal $\mathrm{pH}$ value ranges between 5.43 5.57, water holding capacity ranges between $37.1 \%-38.9 \%$, tenderness ranges between $6.02-8.35$ and cooking loss range between $40.26 \%-49.72 \%$. Total plate count showed that the number of Escherichia coli, Staphylococcus aureus, and Salmonella sp. contaminated the Bali beef exceeds Indonesia national standard (3932:2008). However, the physicochemical quality of the beef was in the normal range. The characteristics of Bali beef at three points above mentioned are normal $\mathrm{pH}$, stable water holding capacity, high level of tenderness, and low level of cooking loss.
\end{abstract}

Keywords: beef, chemical physical, distribution, microbiology, quality

\begin{abstract}
ABSTRAK
Penelitian ini bertujuan untuk menganalisis kualitas fisiko-kimia dan mikrobiologi daging sapi bali selama distribusi dari rumah pemotongan hewan sampai ke konsumen. Penelitian menggunakan enam ekor sapi Bali asal Nusa Tenggara Timur yang ditransportasikan dengan kapal ternak Camara Nusantra dari NTT (Kupang) menuju Tanjung Priok, kemudian dipotong di RPH Jatimulya. Pengambilan sampel daging sapi pada penelitian ini dilakukan pada tiga titik distribusi: 1) Rumah Potong Hewan, 2). Pasar, 3) Konsumen (daging dibeli konsumen dan disimpan selama 3 hari dalam freezer). Pengukuran nilai pH, daya ikat air, susut masak dan keempukan dilakukan untuk melihat kualitas fisikokimia daging sapi Bali. Analisis kualitas mikrobilogi dilakukan secara kuantitatif untuk Total Plate Count, Escherichia coli, Staphylococcus aureus, and Salmonella sp pada daging sapi Bali. Data yang diperolah dianalisis menggunakan analisis sidik ragam 2 arah. Hasil penelitian menunjukkan bahwa daging sapi selama distribusi memiliki pH dalam kisaran normal antara 5.43 - 5.57, daya mengikat air $37.1 \%$ 38.9\%, keempukan 6.02-8.35 dan susut masak daging 40.26\% - 49.72\%. Total Plate Count, Escherichia coli, Staphylococcus aureus dan Salmonella sp. pada daging sapi selama distribusi belum memenuhi Standar Nasional Indonesia (3932:2008). Kesimpulan penelitian ini adalah kualitas fisikokimia daging sapi untuk pH normal, daya mengikat air yang stabil, keempukan daging yang tinggi dan susut masak dalam kisaran normal.
\end{abstract}

Kata kunci: distribusi, daging sapi, fisiko-kimia, kualitas, mikrobiologi 


\section{INTRODUCTION}

Beef is one of the products of Animal sources protein which contains nutrients needed by the human body for growth and health (Afrila and Firman 2012). Beef consumption in Indonesia increases every year. Indonesian beef consumption from 1993 until 2015 performs fluctuations and tends to rise. In the year of 1993-2015, there was an increasing consumption of beef from $0.704 \mathrm{~kg}^{-1}$ per year to $2.40 \mathrm{~kg}^{-1}$ per year (Ministry of Agriculture 2016). One of the fulfillments of consumption comes from local beef. At present, the distribution of local cattle comes from the central producer in the East Nusa Tenggara region to consumer centers such as Java using the Camara Nusantara cattle ship. Indonesia is an archipelago with a long distribution process so transportation modes must be considered. According to Miranda et al. (2012), the length of transportation can affect stress on livestock so that it has an impact on meat quality. Generally, Indonesian people prefer fresh meat, which is slaughtered at abattoirs and directly sold in traditional markets. Food safety in the supply of fresh meat, when selling in traditional markets, must be considered. The meat is stored in an open space that is very vulnerable to contamination so that it affects the quality and the shelf life becomes shorter.

Beef has a high protein content and contains essential amino acids, iron, zinc and vitamins A, B12, B6, and $\mathrm{E}$ (Nfor et al. 2014). The nutritional content becomes a suitable medium for microbial growth causing damage to meat (Kim et al. 2018). Beef quality is influenced by internal and external factors, so it needs to be considered during the process of slaughtering, handling, and distribution properly and correctly to reduce microbial contamination and extend the shelf life of meat. Beef sold on the market is often contaminated by mesophilic bacteria, because lack of attention on sanitation and hygiene aspects on meat handling. As a result, bacterial growth is accelerating. Pathogenic bacteria can cause foodborne disease, which is the result of digestion and absorption of food containing microbes by the human body (Heredia and Garcia 2018).

Microbial contamination causes damage to meat thus it will shorten the shelf-life of meat and reduce the quality and quantity of meat (Shah et al. 2014). In order to reach good quality and safety of meat produced by slaughterhouses, aspects of sanitation and hygiene must be prioritized at the beginning of production, on handling meat process and distribution process to consumers. One treatment that affects the quality and safety of meat is the distribution process. The condition and duration of meat distribution can affect the quality of beef produced. Pathogenic bacteria from meat can be found from the production chain including the production process, transportation, and the low cleanliness of slaughterhouse management (Cho et al. 2017). A research done by Raifah (2018) reported the quality of physicochemical and microbiology of beef during the cold chain distribution from modern slaughterhouses at Bogor. Total Plate Count of Escherichia coli, Staphylococcus aureus, and Salmonella sp. population showed that the population were under the national standard. Some factors affecting quality and safety of meat were the management of slaughterhouses and distribution process. Based on the reasons above, it is interesting to analyze the quality of physico-chemical and microbiology of Bali beef that is transported by Camara Nusantara ship during the distribution process from slaughterhouses to consumers. Therefore, this study aimed to test food safety standards of Bali beef through physics, chemical and microbiological quality of fresh meat at three points, namely at slaughterhouses, at market, and at consumers' storage.

\section{MATERIALS AND METHODS}

\section{Sampling Method}

This study used six heads of Bali cattle from East Nusa Tenggara transported by the Camara Nusantara ship from Kupang to Tanjung Priok and by truck to slaughterhouse. The cattle were slaughtered in the Jatimulya slaughterhouse at Bekasi, West Java. Cattle were slaughtered at three different times containing 2 cattle of each slaughter process. Slaughtering of cattle was carried out after the cattle were conducted a reconditioning after transportation for 1 week. The carcass was then distributed and samples were taken at three points, namely: (1) slaughterhouses (beef was sampled and packed for analysis); (2) market (beef after 4 hours in the traditional market is packed and analyzed); and (3) consumers (beef was sampled after purchased by consumers and stored for 3 days in the freezer). The samples were taken from part of eye round.

\section{Beef Characteristic Analysis}

Beef characteristic analysis consisted of physicochemical quality and microbiological condition. The physicochemical quality of beef included analysis of $\mathrm{pH}$ values using the Hanna $\mathrm{pH}$ meter (Weglarz 2010), water holding capacity, cooking loss and tenderness. To identify $\mathrm{pH}$ values, a total of 50 grams of beef were measured using $\mathrm{pH}$ meter that had been calibrated using $\mathrm{pH} 4$ and $\mathrm{pH} 7$. Press method was used to know water holding capacity. This analysis used Whatman filter paper. A total of 0.3 grams of eye round were clamped between two Whatman filter paper. Wet area is a water area that absorbed by the paper due to clamping method and obtained from the difference area between the outer circle to the inner circle. The water circle was measured by Hruden Planimeter. Physical analysis of beef tenderness was measured by Warner-Bratzler shear force method. A total of 100 grams of beef were boiled until internal temperature reached $80^{\circ} \mathrm{C}$. Samples were treated by beef corer with a diameter of $1.27 \mathrm{~cm}$ to form a small cut and measured using warner brazler shear force. Physical analysis of cooking loss was measured by calculating the difference of beef weight. Total of 100 grams of beef were boiled until internal temperature reached $81^{\circ} \mathrm{C}-82^{\circ} \mathrm{C}$. After samples were drained, cooled, and weighed, the difference between fresh meat weight and cooked meat weight were considered as the beef cooking loss.

The microbiological analysis on beef were done by aseptic method. The first step was mashing the beef as much as $25 \mathrm{~g}$ and put into $225 \mathrm{~mL}$ buffered peptone water (BPW) to obtain dilution 101 . The solution was transferred as much 
as $1 \mathrm{~mL}$ aseptically into $9 \mathrm{~mL}$ of buffered peptone to obtain dilution 102, the same treatment was done up to dilution 104, 105, and 106. The next step was analyzing Total Plate Count of agar media (PCA) of 104, 105, and 106 meat dilution (Pelczar and Chan 2008). The microbial quantitative analysis of Escherichia coli used eosin methylene blue agar (EMBA) and microbial quantitative analysis Salmonella $s p$ media used xylose lysine deoxycholate agar (XLDA) media at dilution 101, 102, and 103 according to Chai et al. (2017). Quantitative analysis of Staphylococcus aureus used baird parker agar (BPA) at dilutions 101, 102 and 103 according to Addo et al. (2015).

\section{RESULTS AND DISCUSSION}

\section{Quality Microbes Beef}

Bali cows were transported using Camara Nusantara Cattle Ship from Tenau port, East Nusa Tenggara to Tanjung Priok Port, Jakarta for 4-5 days. Loading and unloading were carried out at Tanjung Priok port and Bali cattle were transported by truck from the transit cage in Bulog Andini region Cibitung, Bekasi. Bali cows were transited for one night then transported by a truck to Jatimulya slaughterhouses, Tambun, Bekasi. Newly arrived cattle are reconditioned for about 4-7 days with water, forage feed, and tofu pulp before being slaughtered. This is done to eliminate stress on livestock due to transportation. According to Arms and Mariko (2007), modes of transportation, length of transportation, frequency of loading and unloading of livestock, and conditions of transportation modes are factors that can cause livestock stress after transportation so that it has an impact on meat quality (Miranda et al. 2012).

The slaughtering system was done traditionally by tied and rolled on the floor and then the cattle are slaughtered. After blood comes out completely and the blood around the cattle and the floor is cleared using running water, the heads, legs, and tails of cattle was cut. The carcass was hung using a pulley to facilitate the process of cleavage and the innards are removed. Then, the carcass is cut into four parts. Handling process is then performed by weighing the carcass to find out the percentage of the carcass. It is then directly put in a pick-up car that is open for distribution to traditional markets in the Bekasi area.

The Bali cattle slaughtered at Jatimulya slaughterhouse was distributed to traditional markets by pickup trucks without plastic or vacuum packaging. After being transported to traditional markets, then the process of bone separation and slaughtering was done by meat traders in the market. The meat was hung and displayed at room temperature until consumers buy it. Beef was bought by consumers and handled beef was stored for 3 days in the freezer. Calculation of meat microbial population was done during the distribution process from slaughterhouse to traditional markets and then to consumers. It can be seen in Table 1.

\section{Total Microbes (Total Plate Count)}

Total Plate Count (TPC) analysis showed that in distribution process, that is meat in slaughterhouses, meat at the market and meat after 3 days stored by consumers were not significantly different $(\mathrm{P}>0.05)$. The average amount of total microbes of meat in slaughterhouses and meat in consumers was still within safe limits to consume, but meat at market exceeds safe consumption limits. According to SNI (Indonesia National Standard) No. 3932 in 2008 the maximum limit of TPC in carcasses, $6 \mathrm{log} \mathrm{CFU} \mathrm{g}^{-1}$ is the maximum limit of TPC in meat. The high number of microbes in meat indicated contamination occur right after beef was slaughtered and market is the initial place where contamination begins. In addition, this contamination

Table 1. Microbe population $\left(\log \mathrm{cfu} \mathrm{g}^{-1}\right)$ on beef at different chain distribution and different slaughtering time

\begin{tabular}{|c|c|c|c|c|}
\hline \multirow[t]{2}{*}{ Tests } & \multirow[t]{2}{*}{ Slaughtering time } & \multicolumn{3}{|c|}{ Distribution Chain } \\
\hline & & Slaughterhouse & Market & Consumers \\
\hline Total Plate Count & Cutting 1 & $5.90 \pm 0.13$ & $6.49 \pm 0.62$ & $5.77 \pm 0.13$ \\
\hline \multirow[t]{3}{*}{$\left(\log \mathrm{cfu} \mathrm{g}^{-1}\right)$} & Cutting 2 & $5.56 \pm 0.07$ & $5.96 \pm 0.09$ & $6.01 \pm 0.04$ \\
\hline & Cutting 3 & $6.44 \pm 0.04$ & $6.67 \pm 0.16$ & $6.20 \pm 0.49$ \\
\hline & Average & $5.97 \pm 0.45$ & $6.37 \pm 0.37$ & $5.99 \pm 0.21$ \\
\hline Escherichia coli & Cutting 1 & $2.32 \pm 0.07$ & $2.43 \pm 0.07$ & $1.92 \pm 0.15$ \\
\hline \multirow[t]{3}{*}{$\left.(\log \text { cfu g })^{-1}\right)$} & Cutting 2 & $1.80 \pm 0.14$ & $1.81 \pm 0.30$ & $1.00 \pm 0.00$ \\
\hline & Cutting 3 & $0.65 \pm 0.92$ & $1.35 \pm 0.07$ & $1.15 \pm 0.21$ \\
\hline & Average & $1.59 \pm 0.85$ & $1.86 \pm 0.54$ & $1.36 \pm 0.49$ \\
\hline Staphylococcus aureus & Cutting 1 & $2.92 \pm 0.07$ & $3.06 \pm 0.03$ & $2.67 \pm 0.03$ \\
\hline \multirow[t]{3}{*}{$\left(\log \mathrm{cfu} \mathrm{g}^{-1}\right)$} & Cutting 2 & $2.00 \pm 0.09$ & $2.43 \pm 0.05$ & $2.18 \pm 0.07$ \\
\hline & Cutting 3 & $2.35 \pm 0.09$ & $2.70 \pm 0.08$ & $2.13 \pm 0.10$ \\
\hline & Average & $2.42 \pm 0.47 \mathrm{a}$ & $2.73 \pm 0.32 b$ & $2.33 \pm 0.30 \mathrm{a}$ \\
\hline \multirow[t]{3}{*}{ Salmonella sp. } & Cutting 1 & (+) $2 / 2$ & (+) $2 / 2$ & (+) $2 / 2$ \\
\hline & Cutting 2 & $(+) 1 / 2$ & $(+) 1 / 2$ & (+) $1 / 2$ \\
\hline & Cutting 3 & (-) $2 / 2$ & $(+) 1 / 2$ & $(+) 1 / 2$ \\
\hline
\end{tabular}

Numbers at the same line or row that followed by different letters shows the significant difference $(\mathrm{p}<0.05)$. ${ }^{*}(+) 1 / 2$ : detected Salmonella $s p$ from 2 samples observed 
was caused by lack preparation and meat handling after slaughtering as well as low level of sanitation and hygiene during distribution to markets. Environment, equipment and traders are sources of contaminants. The process of cutting carcass and meat hanging without being stored in the refrigerator are also considered as sources of contaminants. This is in line with Nurwantoro et al. (2012) who stated that bacterial contamination will increase during distribution and marketing. Distribution methods, workers and sellers are factors that increase contamination. According to Raoul et al. (2015) meat contamination was also obtained from an unhealthy environment that is from dirty hands, polluted water, and soil. The decrease in total meat microbes in consumers is influenced by the storage process in the freezer which affects the inhibited bacterial growth rate. According to Vieira et al. (2009), frozen storage can affect the microbiological quality and physicochemical characteristics because it progressively deteriorates during storage.

In the process of meat production in slaughterhouses, it is expected that the handling of meat after the slaughter in slaughterhouses can reduce the rate of microbial growth. Vacuum packaging can reduce the microbial contamination of meat during distribution and sale in market. In addition, application of cold chain distribution can maintain the quality of meat in terms of microbe, namely microbial contamination from environment of the distribution equipment (car box) and personal handling of the meat. Microbial contamination in slaughterhouses and during distribution can be reduced by implementing a good sanitation and hygienic system during the carcass/ meat production process from environment, equipment, and workers. An implementation of good handling processes and good manufacturing practices during production in slaughterhouse and every distribution process until meat is accepted by consumers to maintain the quality and safety of meat products is expected to be done.

\section{The Results of Escherichia coli Analysis}

The results of Escherichia coli analysis showed that in the distribution process, meat in slaughterhouses, meat in the market and meat after 3 days at consumers' storage were not significantly different $(\mathrm{P}>0.05)$. The maximum number of $E$. coli in meat distribution process is $1 \log \mathrm{CFU}$ $\mathrm{g}^{-1}$ which is based on the SNI standard No. 3932 in 2008. $E$. coli bacteria is an indicator of contaminated sanitation on the hygienic status of food products. The amount of $E$. coli that outpaced $2 \log \mathrm{CFU} \mathrm{g} \mathrm{g}^{-1}$ indicated that the product is dangerous for consumers' health, so it is not suitable for consumption. There is a need to improve hygienic system and sanitation of meat production. The average amount of $E$. coli during distribution and in the market increased because consumers are allowed to easily choose and touch meat. In addition, meat is stored at room temperature in the market which was very susceptible to the growth of pathogenic bacteria. The temperature in the range of $4{ }^{\circ} \mathrm{C}$ to $60{ }^{\circ} \mathrm{C}$ can be a place for the growth of pathogenic bacteria (Omer et al. 2015). The amount of E. coli decreased during consumers' storage. Frozen meat will inhibit bacterial growth (Vieira et al. 2009). E.coli also presents during distribution, cutting process and meat handling. The presence of this pathogenic contaminant is due to unhygienic equipment used and unhygienic hands of workers during cutting process, meat handling, and distribution from slaughterhouse to markets and consumers. Meat contamination was started from the time of the slaughtering of cattle until consumption. The existence of $E$. coli bacterial contaminants is due to sanitation from slaughterhouses that do not meet standards and poor work management (Bontong et al. 2012).

\section{The Results of Staphylococcus aureus}

The results of the analysis of Staphylococcus aureus in the distribution process, meat in slaughterhouses, meat in the market and meat after 3 days at consumers' storage gave a significantly different effect $(\mathrm{P}<0.05)$. The average number of Staphylococcus aureus per distribution process treatment was above the maximum limit of SNI Quality of Carcass and Beef No. 3932 in 2008 which is 2 log CFU $\mathrm{g}^{-1}$. The presence of these bacteria is caused by microbial contamination during the production process, distribution, and market sales. Fluctuating beef storage temperature can cause the growth of Staphylococcus aureus (Obeng et al. 2013), this is found in meat during distribution and sale in markets. The meat is stored at room temperature until it is purchased by consumers. High nutrient content in meat also affects bacterial growth. Bacterial or microbial growth in meat is influenced by water content, fat protein, and minerals needed by bacteria to live and breed (Nurwantoro et al. 2011). Besides this, contamination of Staphylococcus aureus can be caused by organisms and living things that come from people who handle food (Pelczar and Chan 2008). Staphylococcus aureus is an enterotoxigenic bacterium that is capable of producing toxins in a population of $5 \operatorname{logs}$ CFU g- 1 so that it becomes a benchmark of food safety for consumers' health (Health Protection Agency 2009).

\section{Salmonella sp Analysis}

During the distribution process, meat in the slaughterhouse, meat in the market and meat after consumed showed that meat contained Salmonella sp. This is not in accordance with the provisions of SNI No. 3932 in 2008 regarding the quality of carcasses and meats stating the content of Salmonella sp. in fresh meat is negative per $25 \mathrm{~g}$. The existence of Salmonella sp. during the distribution process caused by the handling process and management of distribution process that is not good. Lack of sanitation and hygiene application as well as good work producer standards that causes contamination during the cutting process of equipment as well as personal and environment then the distribution of meat that is not stored in refrigerated cars or coolboxes. This is occured when meat is on the market. Meat in the market store at room temperature affects the growth of Salmonella $s p$ bacteria that are aerobic and facultative anaerobes and can grow at temperatures of $5{ }^{\circ} \mathrm{C}$ to $54{ }^{\circ} \mathrm{C}$ with an optimum temperature of $35^{\circ} \mathrm{C}-37^{\circ} \mathrm{C}$ (Gray and Fedorka-Cray 2012; Nwabor et al. 2015). Meat is a beneficial source of protein for bacteria to grow and multiply at optimum temperatures (Seoparno 2015). However, the growth of Salmonella $s p$ will be inhibited at temperatures of $<7^{\circ} \mathrm{C}, \mathrm{pH}<3.8$ or water activity 
$<0.94$ (Nwabor et al. 2015). This is shown by meat that is stored for 3 days in consumers' freezer. Salmonella sp. are a pathogenic bacterium that can cause infections that attack the digestive tract (Pelczar and Chan 2008). The presence of Salmonella $s p$ on the product has the potential to cause infection in consumers' health. It will be dangerous if the cooking of meat is less than perfect and the need for good meat handling from the beginning of the production process until it is ready to eat.

\section{Physical Chemical of the Beef}

In the Jatimulya slaughterhouse, there is no meat handling after slaughtering such as beef ageing procedure or deboning. Carcass after slaughtering distributed to traditional markets by pickup trucks without packaging plastic or vacuum. After distribution, carcass is handled in market such as cutting and is deboned then it is displayed and hung on the table at the room temperature. After that beef is ready to sell to consumers. Table 2 shows that physical chemical of Bali beef during distribution process from slaughterhouses to market until customers received it.

\section{pH Analysis}

$\mathrm{pH}$ analysis was done in distribution process, at slaughterhouses, and at markets as well as after 3 days at consumers' storage showed significantly different effects ( $\mathrm{P}$ $<0.05)$. Different cutting time factors did not significantly affect the $\mathrm{pH}$ of meat. This showed that the $\mathrm{pH}$ value of the meat was stable at the time of cutting carried out in slaughterhouses Jatimulya. Stable $\mathrm{pH}$ values can be influenced by the uniform age of cattle when slaughtering and handling of cattle before slaughtering with a fresh reconditioning time in Jatimulya slaughterhouses. This is in line with Komariah et al. (2009) The stability of $\mathrm{pH}$ values in meat in slaugh- terhouses is due to the uniformity of cattle age, the management of standardized cattle, the process of slaughtering and production that has been standardized, and the uniformity of beef management from upstream to downstream (Komariah et al. 2009). The $\mathrm{pH}$ value was influenced by the meat condition of cattle before and during slaughtering which affects glycogen levels in muscles. The condition of cattle that are stressed before slaughtering will also affect the availability of glycogen in the muscles and will affect the high or low $\mathrm{pH}$ value of post-meat. Therefore, it is expected that the condition of livestock before being slaughtered and when slaughtered reduces stress on livestock by the time of reconditioning after standardizing livestock distribution and handling so that it does not affect the normal $\mathrm{pH}$ value of meat i.e. $\mathrm{pH}$ 5.3-5.9. Carcass handling after slaughtering can affect the quality of meat such as withering of meat at low temperatures which can inhibit the rate of decrease in $\mathrm{pH}$ so that it can affect the physical quality of other meats such as tenderness which can make the meat softer than that withering can inhibit the growth of microbes in meat thus reducing microbial fir.

Meat distribution factors showed the average of $\mathrm{pH}$ value that has decreased in every step of distribution process, from slaughterhouses to consumers. Animals after slaughtering will decrease $\mathrm{pH}$, this affects the process of glycolysis in which the amount of lactic acid produced by glycogen at postmortem will be depleted so that the $\mathrm{pH}$ of the meat has decreased. The $\mathrm{pH}$ value of meat after the market which has decreased can be influenced by the activity of meat microorganisms originating in the environment, the slaughtering process and during distribution. Also, the $\mathrm{pH}$ value of meat at consumers' storage has decreased due to the freezing process during storage for three days.

Tabel 2. Beef physical and chemical values in different slaughtering week and distribution chain.

\begin{tabular}{lcccc}
\hline Tests & Slaughtering time & \multicolumn{3}{c}{ Distribution Chain } \\
\cline { 3 - 5 } & & Slaughtering & Market & Consumers \\
\hline $\mathrm{pH}$ & Cutting 1 & $5.49 \pm 0.11$ & $5.47 \pm 0.16$ & $5.35 \pm 0.07$ \\
& Cutting 2 & $5.63 \pm 0.04$ & $5.61 \pm 0.02$ & $5.36 \pm 0.04$ \\
& Cutting 3 & $5.61 \pm 0.03$ & $5.47 \pm 0.05$ & $5.59 \pm 0.11$ \\
& Average & $5.57 \pm 0.07$ & $5.51 \pm 0.08$ & $5.43 \pm 0.13$ \\
Water Holding Capacity & Cutting 1 & $38.8 \pm 0.19$ & $38.41 \pm 2.27$ & $37.0 \pm 1.6$ \\
$(\%)$ & Cutting 2 & $37.8 \pm 2.41$ & $36.28 \pm 1.7$ & $35.6 \pm 0.8$ \\
& Cutting 3 & $40.1 \pm 0.23$ & $40.71 \pm 0.75$ & $38.7 \pm 1.4$ \\
Tenderness & Average & $38.90 \pm 1.17$ & $38.46 \pm 2.22$ & $37.1 \pm 1.57$ \\
$\left(\mathrm{~kg}\right.$ cm $\left.{ }^{-2}\right)$ & Cutting 1 & $8.2 \pm 1.13$ & $8.6 \pm 2.55$ & $5.65 \pm 0$ \\
& Cutting 2 & $6.45 \pm 1.77$ & $7.85 \pm 2.62$ & $6.15 \pm 0$ \\
& Cutting 3 & $10.4 \pm 0.28$ & $7.9 \pm 3.11$ & $6.52 \pm 0.1$ \\
Cooking Loss & Average & $8.35 \pm 1.98$ & $8.12 \pm 0.42$ & $6.02 \pm 0.32$ \\
$(\%)$ & Cutting 1 & $54.4 \pm 1.98$ & $47.6 \pm 4.12$ & $36.7 \pm 7.3$ \\
& Cutting 2 & $46.4 \pm 4.71$ & $49.3 \pm 3.61$ & $44.6 \pm 0.8$ \\
& Cutting 3 & $47.9 \pm 4.14$ & $52.2 \pm 5.2$ & $39.4 \pm 3.2$
\end{tabular}

Number in the same line or row followed by different letters shows significant difference $(\mathrm{p}<0.05)$. 


\section{Water Holding Capacity}

Water binding capacity (DMA) is described by the percentage of free water $\left(\mathrm{mgH}_{2} \mathrm{O}\right)$. The results of analysis on the mg $\mathrm{H} 2 \mathrm{O}$ value showed a significantly different effect $(\mathrm{P}<0.05)$ in the distribution process, meat in slaughtered house, meat in the market and meat after 3 days in consumers. On the contrary, the different cutting times and interactions between the two factors had no significant effect on the value of $\mathrm{mgH}_{2} \mathrm{O}$ in beef. The average of $\mathrm{mg} \mathrm{H}_{2} \mathrm{O}$ during the distribution process, namely packaging process in slaughtered house, selling process in the market and storing process after 3 days in consumers respectively $38.9 \%, 38.46 \%$ and $37.1 \%$. The value of $\mathrm{mg}$ $\mathrm{H}_{2} \mathrm{O}$ is inversely proportional to the value of water binding power. The results showed a decrease in $\mathrm{mg}_{2} \mathrm{O}$ during the distribution process. This is influenced by a decrease in meat $\mathrm{pH}$ during distribution. According to Florek et al. (2009), the decrease of meat $\mathrm{pH}$ and duration of withering affect the value of $\mathrm{mgH}_{2} \mathrm{O}$. At isoelectric $\mathrm{pH} 5$ to 5.1, the meat protein is uncharged, the $\mathrm{pH}$ is above the isoelectric, the positive charge is released, so that the negative charge is surplus and myofilament rejection results in the formation of space for water molecules as well as increases the water binding capacity. The $\mathrm{pH}$ below isoelectric is due to positivity load access that will result in myofilament rejection resulting in the formation of space for water molecules and increasing water binding capacity (Soeparno 2015).

\section{Tenderness}

ANOVA analysis results showed that the meat distribution factor and cutting time factor as well as the interaction between the first factors that is the distribution of the meat chain when in the slaughterhouse, in the market and in consumers' storage after 3 days and the second factors that is the different cutting time at the first cut, second cut, and the third cut had no significant effect $(\mathrm{P}>0.05)$ on beef tenderness. The value of meat tenderness has decreased during the distribution process that is in slaughterhouses, in the market and in consumers after 3 days, while the value of meat tenderness at different cutting times tends to be stable. Tenderness is one of the main indicators and factors of consideration for consumers in choosing good quality meat (Joo et al. 2009). The average tenderness of meat after 3 days in consumers' storage had decreased because the frozen storage process causes the meat to be tender. This happens when meat has passed the rigor mortise phase so that the meat becomes soft. The length of frozen meat storage affects the tenderness of the meat so that the meat becomes more tender. Storage time causes the action of proteolytic enzymes thereby increasing meat tenderness (Mungure et al. 2016).

\section{Cooking Loss}

Beef shrinkage analysis shows that the distribution process factors, namely meat in slaughterhouses, meat in the market and meat in consumers' storage after 3 days and different time slaughter factors (first cut, second cut, and third cut) also the interaction between the two treatments gave had no significant effect $(\mathrm{P}>0.05)$. The average value of cooked shrinkage during meat distribution decreased from the slaughterhouse to the market and to the consumers.
The value of cooked shrinkage was influenced by decrease level of meat $\mathrm{pH}$ during meat distribution and water holding capacity. Lower cooked meat shrinkage had relatively better quality than larger cooked meat shrinkage because there will be less loss of nutrients during cooking. According to Soeparno (2015), the $\mathrm{pH}$ value of meat influences cooking losses in meat. The high value of cooking shrinkage is an indicator of weakening of protein bonds so that the ability to bind the liquid flesh is weakened and a lot of liquid meat comes out because the water binding capacity decreases.

\section{CONCLUSION}

The beef characteristics of bali cattle from East Nusa Tenggara (using Camara Nusantara cattle ship transportation) at every step of distribution process, that is slaugterhouse, traditional markets and consumers were in the standard or normal range of $\mathrm{pH}$, standard level of water holding capacity, high level of tenderness, and low level of cooking loss. The microbiology quality of beef did not fulfill Indonesia National Standard SNI No. 3932 in 2008.

\section{ACKNOWEDGEMENT}

The authors thank to ALIN (Animal Logistics Indonesia Netherland) - NICHE (Netherland Initiative for Capacity Development in Higher Education) 2018-2019 and Rizdika Mardiana for support funding of this research (NIHCE/IDN.223).

\section{REFERENCES}

Addo, K.K., V.Y Adjlei, G.I Mensah \& D.J Sillah. 2015. Microbial quality and antibiotics residue in raw beef from selected abattoirs in Accra, Ghana. Int J Trop Dis Health. 6(1):20-16.

Afrila, A., \& J. Firman. 2012. Tenderness, pH and water activity (Aw) of spices dried meat on various concentrate of ginger extract (Zingiber Officinale Roscoe) and different soaking time. JITEK. 7(2):6-12.

Arms, S., \& L. Mariko. 2007. Transport and care of cattle. Department of primary industries of Victoria. ISBN 978-1-74199-250-2.

Bontong, R.A., H. Mahatmi \& I.K Suada. 2012. Kontaminasi bakteri Escherichia coli pada daging se'i sapi yang dipasarkan di kota Kupang Indonesia. Indonesia Medicus Veterinus. 1(5):699-711

Chai, C., S.Y Lee \& S.W Oh. 2017. Shelf life charts of beef according to level of bacterial contamination and storage temperature. JFST. 81(3):50-57

Cho S, S.M Kang, P. Seong, G. Kang, Y. Kim, J. Kim, S. Chang, B. Park. 2017. Effect of Aging and Freezing Conditions on Meat Quality and Storage Stability of 1++ Grade Hanwoo Steer Beef: Implications for Shelf Life. Korean J. Food Sci. An. 37(3): 440-448

Gray J.T., \& P.J Fedorka-Cray. 2012. Salmonella: Foodborne Diseases. Ed ke-2. Cliver D.O. and Riemann, H. (Eds.). New York (US): Academic Pr.

Heredia N., \& S. Garcia. 2018. Animals as sources of foodborne pathogens: A review. Anim Nutr 4(3):250-255 
Health Protection Agency. 2009. Guidelines for Assessing the Microbiological Safety of Ready-to-Eat Foods. Health Protection Agency. London

Joo S., G. Kim, Y. Hwan \& Y. Ryu. 2013. Control of fresh meat quality through manipulation of muscle fiber characteristics. Meat Sci. 95(4):828-836

Kim S.J., A.R. Cho, \& J. Han. 2018. Antioxidant and antimicrobial activities of leafy green vegetable extracts and their applications to meat product preservation. Food Control. 29 (1) 112-120

Komariah S., Rahayu, \& Sarjito. 2009. Physical characteristics of beef, buffalo and lamb meat on different post mortem periods. Bul Petern. 33(3):183189.

Miranda-de G.C., M.I.S Sotelo, C.P Linares, F.F Saavendra, M Villarroel, C Sanudo, G.A Maria. 2012. Effects of two transport systems on lamb welfare and meat quality. Meat Sci. 92(4):554-561

Nfor B.M., M. Corazzin, F.A Fonteh, A.Sepulcri, N.T Aziwo, E Piasentier. 2014. Fatty acid profile of zebu beef cattle from the Central African sub-region. Africa J Anim Sci. 44 (2):148-154.

Nurwantoro V.P., Bintoro, A.M Legowo, A.Purnomoadi, L.D Ambara, A. Prokoso, S. Mulyani. 2011. Microbiological and physical properties of beef marinated with garlic juice. JITAA. 36(3): 166-170.

Nurwantoro V.P., Bintoro, A.M Legowo, A.Purnomoadi, L.D Ambara, A. Prokoso, S. Mulyani. 2012. Microbiological properties of beef in various meat shops at Semarang, Indonesia. JITAA. 37(2): 97-102.

Nomor Seri Standar Internasional [ISSN]. 2016. Outlook Daging Sapi ISSN: 1907-1507. Pusat Data dan Sistem Informasi Pertanian Sekertaris Jenderal Kementrian Pertanian. Jakarta.

Nwabor O.F., I. Dickson, Q.C. Ajibo. 2015. Epidemiology of Salmonella and Salmonellosis. International Letters of Natural Sciences. 47(2015):54-73
Obeng A.K, F.S Johnson, S.O Appenteng. 2013. Microbial Quality of Fresh Meat from Retail Outlets in Tolon and Kumbungu Districts of Northern Region of Ghana. IJST. 2(6):423-428

Omer M.K., S.J Hauge, O.Oyvin, B. Moen, A. Ole, J.R Ole, P. Miguel, D. Sissel, H. Ole, T. Nesbakken. 2015. Effects of hygienic treatments during slaughtering on microbial dynamics and contamination of sheep meat. Int J of Food Microbiol. 194(2): 7-14

Raifah, Y.N. 2018. Evaluasi Penerapan GMP dan SSOP pada RPH Kategori II dan Distribusi Rantai Dingin terhadap Kualitas Daging Sapi. Phd Thesis. Bogor Agriculture university, Bogor, Indonesia

Pelczar M.J and E.C.S Chan. 2008. Elements of Microbiology. Mc Graw Hill Book Company. New York

Raoul B.A, P.N Rodrigue, S.S Kamdemm, J.E Jean, B.A Rianatou. 2015. Microbial load of beef sold in the traditional slaughterhouse and butcher shops in Northern Cameroon. Int J Vet Sci. 4(4):183-189.

Shah M.A, S.J Bosco \& S.A Mir 2014. Anti-oxidant effect of extracts of kinnow rind, pomegranate rindand seed powders in cooked goat meat patties. Meat Sci. 85 (1) $155-159$

Standar Nasional Indonesia (SNI 3932, 2008). Mutu Karkas dan Daging Sapi. Badan Standardisasi Nasional (BSN). Jakarta.

Soeparno. 2015. Ilmu dan Teknologi Daging. Cetakan Keenam. Gadjah Mada Univ Pr. Yogyakarta

Vieira C. M.T Diaz, B. Martinez, M.D Garcia. 2009. Effect of frozen storage conditions (temperature and length of storage) on microbiological and sensory quality of rustic crossbred beef at different states of ageing. Meat Sci. 83(3):398-404.

Weglarz A. 2010. Meat quality defined based on $\mathrm{pH}$ and color depending on cattle category and slaughter season. Anim Sci. 55:(12), 548-556. 